\title{
Zeydî Hadis Yorumu: Muhammed B. Yahya (Ö. 310/923) Örneği
}

\author{
Kadir DEMiRCi
}

\begin{abstract}
Zeydî Hadis Yorumu: Muhammed B. Yahya (Ö. 310/923) Örneği

Özet

Muhammed b. Yahya'nın kendisine sorulan hadislere yaptığı yorumlar onun hadis anlayışını göstermesi bakımından önemlidir. İtikatta Mutezile gibi düşünen bir Zeydî imamı olan Muhammed b. Yahya'nın hadislere yaklaşımını gösteren örnekler Mutezile anlayışına sahip bir alimin hadislere nasıl yaklaşabileceği konusunda fikir vermesi bakımından oldukça dikkat çekicidir. Zira Mutezile âlimlerinin itikat konusundaki hadislerle ilgili görüşleri az çok bilinmekle birlikte itikat alanının dışındaki hadislere yaklaşımları ise pek bilinmemektedir. İmam Muhammed hadisler konusunda oldukça hassasiyet göstermektedir. Zira ona göre Kur'an'a aykırı çok hadis bulunmaktadır. O nedenle imam Muhammed hadis yorumlarında Kur'an'ı öne çıkarmakta, Kur'an ve hadis birlikteliğine önem vermektedir. $\mathrm{O}$, $\mathrm{Hz}$. Peygamber'in Kur'an'la uyum içerisinde olan sünnetinin örnek alınması gerektiğini düşünmektedir. İmam Muhammed Hz. Peygamber'den nakledilen hadisleri Kur'an, sahih sünnet, akıl ve dinin temel ilkeleri istikametinde yorumlamaktadır.
\end{abstract}

Anahtar Kelimeler: İmam Muhammed, Zeydiyye, Mutezile, Hadis Yorumu

\section{Giriş}

Zeydiyye Şia'nın bir koludur. Bu isim Ali Zeynelâbidin'in oğlu olan imam Zeyd'den (ö.122/740) gelmektedir. Kelime 'Zeyd'in yolunu takip edenler' anlamında mezhebin ismi olarak kullanılmaktadır. İmam Zeyd, tıpkı dedesi Hz. Hüseyin gibi zalim Emevi halifesi Hişam b. Abdilmelik’e karşı müca-

* Kadir DEMiRCi, Doç.Dr., Eskişehir Osmangazi Üniversitesi, Temel İslam Bilimleri Bölümü, kadirdemirci68@gmail.com, ORCID ID orcid.org / 0000-0001-7921-6215 
Kadir DEMiRCi

dele etmiş ve bu uğurda şehit olmuştur. Şehâdetinin ardından İmam Zeyd'in davası, siyâsî, ilmî görüşleri, oğulları ve sevenleri tarafından devam ettirilmiştir. Öyle ki Yemen'de Zeydîler tarafından hicrî 284/897 yılında güçlü bir devlet kurulmuştur. Bu devletin Yemen'deki hakimiyeti inişli-çıkışlı olmakla birlikte on bir asır boyunca devam etmiştir. (Üzüm, 2013, 44/326) Başlangıçta siyâsî bir hareket olarak ortaya çıkan Zeydiyye, tarihî süreç içerisinde müctehid imamlarının görüşleriyle müstakil bir itikat ve fıkıh mezhebine dönüşmüştür. Sonuç olarak Zeydiyye mezhebine ait zengin bir literatür ortaya çıkmıştır. Bu zengin literatür mezhebin devamında büyük rol oynamıştır. Nitekim Zeydîler, bugün de Yemen'in kuzeyinde Sa'de bölgesinde varlıklarını sürdürmektedir. Çağdaş Zeydîler kadim Zeydî imamların eserlerini neşretmekte ve onların görüşlerinin yayılmasına hizmet etmektedirler. Bu Zeydi imamlardan biri de Muhammed b. Yahya'dır.

Muhammed b. Yahya, (ö.310/923) Zeydiyye mezhebinin sistemleşmesine ve Yemen'de yerleşmesine vesile olan, Yemen'de Zeydiyye devletini kuran, yaptığı mücadele ile insanları hakka, hidayete, doğruya çağıran ve bundan dolayı da el-Hâdî lakabıyla anılan imam Hâdî ile'l-Hak Yahya b. el-Hüseyin'in (ö. 298/901) oğludur. Diğer taraftan imam Zeyd'den sonra Zeydiyye mezhebinin kurucu imamlarının başında gelen ve Binyamin Abrahamov tarafından "Müslümanların Eflatun'u” olarak nitelendirilen büyük kelamcı Kâsım er-Ressînnin (ö.246/860) de torunudur. (Ressi, 2001: 30) Muhammed b. Yahya'nın hem ilmi hem fikri hem de şahsiyeti böyle güçlü bir aile geleneğinden gelmektedir. İlim ve fikir yönünden zengin aile geleneği Muhammed b. Yahya'nın kendi şahsî istidadı ve gayretiyle de birleşerek İslâmî ilimlerde derin vukûfiyeti olan bir âlimin ortaya çıkmasına vesile olmuştur.

Muhammed b. Yahya'nın kesin olmamakla birlikte hicrî 278 yılında cebel-i Res'de doğduğu ifade edilmektedir. (Vecih, 1999: 1013) Ancak onun bu yıllarda yedi yaşında olduğuna dair de mülahazalar vardır. (Mecmu', I, 10) İmam Muhammed önce babasının ilmini, ondan da büyük dedesi Kâsım er-Ressî́nin ilmini tevârüs etmiştir. O, aynı zamanda babasıyla beraber savaşlara iştirak etmiş, cihaddan geri kalmamış, ilmin yanında aktivist bir kişiliğe de sahip olmuştur. Geçen zaman içerisinde İmam Muhammed b. Yahya akâid, fıkıh ve Kur'an ilimlerinde yazdığı eserlerle büyük bir üne kavuşmuştur. (Hadâik, II/80) O, İslâmî ilimler yanında edebiyat ile de meşgul olmuş, şiir yazmıştır. (Hadâik, II/81) Özellikle kendisine sorulan meselelere verdiği cevaplar halkın üzerinde etkili olmuştur. Muhammed b. Yahya'nın erkek ve kız olmak üzere çok sayıda çocukları vardır. Oğulları Kasım, İsmail, İbrahim, Ali, Abdullah, Musa, Hasan, Hüseyin ve Yahya'dır. Oğlu Yahya amcasından dedesi imam Hâdî ile'l-Hak Yahya b. el-Hüseyin'in Kitâbu'l-ahkam'ını ve el-Müntehâb'ını nakletmiştir. (Hadâik, II/82; el-ifâde, 133) Babasının vefatından sonra 299 yılında kendisine bey'at edilen imam Muhammed Sa'de şehrinde ikamet etmiş, Hemdan, Necran ve Havlan bölgelerine hükmetmiştir. O da babası gibi Karmatîler ile mücadelesini sürdürmüş, Udeyde bölgesinde ordusunu Karmatîler üzerine sevk etmiştir. (Vecih, 1999: 1013) Kendi yakınlarından gördüğü kötülükler sebebiyle imamet vazifesini 301/913 tarihinde kardeşi Ahmed b. Yahya en-Nâsır'a bırakmış, kendisi uzlete çekilmiş, vefatına kadar ilim ve ibadet ile meşgul olmuştur. İmam Muhammed 310/922 
yllında genç yaşta vefat etmiş ve Yemen'in Sa'de şehrinde babasının yanına defnedilmiştir. (Vecih, 1999: 1013; Hadâik, II/87)

Hemen hemen İslâmî ilimlerin her alanında eserleri olan Muhammed b. Yahya'nın çoğu el yazması halinde bulunan eserlerinin bir kısmı tahkik edilerek yayınlanmıştır. El-Usûl fi'l-adli ve'ttevhid (mahtut) Ecvibetü mesâilü ibn-i Mehdî (mahtut) Ecvibetü Mesâilü ibnu'n-Nâsır, Ecvibetü mesâilü'I-ma'kılî, el-Irâde, Kitâbü'l-meşie, Kitabu'I-büyû', Kitâbü't-tevbe, Kitâbu tefsiri'l-Kur'an, Cevâbu ibn-i Fadli'l-Karmatî, er-Red ale'r-Revâfıd, er-Red ala'I-Karâmita, Kitâbu'r-radâ', Risâletü'limam el-Murtaza ilâ ehl-i Taberistan, er-Resâilu's-Seb'i'l-müntekâ, eş-Şerhu ve'I-beyan fi tefsîri'lKur'an, el-Faslu'I-Merviyy, Fedâilu Emiri'l-mü'minin, Kitâbü'I-Fıkh, Mesâilu'l-câirî, Mesâilü'tTaberiyyin, Mesâilu Abdullah b. Süleyman, Mesâilu'I-Kademiyyin, el-Muğnî ala mezhebi'n-NasırKitabu'n-nübüvve ve'l-imame, Kitabu'I-nevâzil onun eserlerinden bazılarıdır. (Vecih, 1999: 10131015) Muhakkik Abdülkerim Cedban onun bazı eserlerini tahkik ederek iki cilt halinde 'Mecmû'u Resâil-i imam Muhammed' adı ile neşretmiştir. Abdülkerim eserin mukaddime bölümünde imam Muhammed'in otuz iki eserinin ismini zikretmektedir. (Mecmû', l, 13) Mecmû' un birinci cildinde 'el-izâh' adlı eseri yer almaktadır. Bu eser imam Muhammed'e sorulan 291 sorudan oluşmaktadır. Bu soruların çoğu fıkhî sorular olmakla birlikte yetmişten fazlası da hadislerin sıhhati ve anlamı ile ilgilidir. Kitabın son bölümünde 'Mesâil-ü Abdullah b. el-Hasan' ismini taşıyan eser yer almaktadır. Bu eser Mecmû'un birinci cildinin sonunda başlamakta ikinci ciltte devam etmektedir. İmamın bu eseri tefsir ile ilgilidir. Bir önceki eseri gibi bu eser de soru cevap şeklindedir. İmam bu eserinde kendisine sorulan 355 soruyu cevaplamaktadır. Soruların çoğu ayetlerin tefsiri ile ilgilidir. Eserde yetmiş kadar da hadis ile ilgili sorular yer almaktadır. Mecmû'un ikinci cildinde 'Tefsîru Sûreti'l-Kehf' risalesi bulunmaktadır. Adından da anlaşılacağı üzere bu eser Kehf süresinin tefsiri ile ilgili bir risaledir. Daha sonra imam Muhammed'in gafiller topluluğuna hitaben kaleme aldığı, 'el-Gafletü' ismini taşıyan, ayetlerden öğütler, uyarılar içeren bir başka risalesi gelmektedir. Bu risalenin ardından da 'Usûl' adı altında imamın akâid konularına ait iki risalesi yer almaktadır. Bunların ardından da kulun öncelikle Allah hakkında bilmesi gereken şeyleri içeren el-Fasl adında bir buçuk sayfalık bir yazısı bulunmaktadır. Sonra 'Cevâbu ala Ba'zı Karabetihi' başlı̆ıı altında imam Muhammed'in akrabalarına yazdığı bir risale yer almaktadır. Mecmû'un ikinci cildinde İmam Muhammed'in baba tarikiyle rivayet ettiği $\mathrm{Hz}$. Peygamber'in nehyettiği şeyleri içeren seksen yedi hadisin yer aldığı 'el-Menâhî' adlı bölüm bulunmaktadır. (Bkz. Ümit, 2018: 130-136).

Biz imam Muhammed'in hadis yorumlarını içeren bu makalede onun işte bu iki ciltlik Mecmû'u içinde yer alan risâlelerinden kendisine sorulan hadislere verdiği cevapları incelemeyi hedefledik. İtikatta Mutezilî olan bir imamın itikat konuları dışındaki hadislere yaklaşımını göstermesi bakımından bu çalışmanın önem arz edeceğini düşünmekteyiz. Tahmin edileceği üzere imam Muhammed hadislere eleştirel bir şekilde yaklaşmakta ve onları Kur'an, üzerinde icma edilmiş sahih sünnet, akıl ve dinin temel esasları çerçevesinde yorumlamaktadır. Bazı yorumlarında aceleci ve keskin tavırlar takındığı görülse de imamın hadislere yaklaşımı oldukça önemlidir. Zira o, Hz. Peygamber hakkında Kur'an'a muhalif tarzda çokça hadis bulunduğunu dile getirmekte ve bu nedenle hadisler konusunda oldukça hassas davranmaktadır. Kendisine sorulan sorularda muha- 
taplarını Kur'an'a ve Hz. Peygamber'in sünnetine yönlendirmektedir. Zira muhatapların sordukları hadisler içerisinde Kur'an'ın içeriği ile uyuşmayan, aynı zamanda akla da aykırı bulunan dinen insana bir fayda da getirmeyecek türde rivayetler yer almaktadır. İmam Muhammed, bu rivayetlerin genellikle cahil kişiler tarafından uydurulduğunu dile getirmektedir. Soru ve cevap şeklindeki bir sistematiğe sahip olan eserlerinden anlaşıldığı kadarıyla yaşadığı dönem içerisinde hadisler insanların zihinlerini oldukça meşgul etmektedir.

İmam Muhammed'in bu eserlerinde kendisine bazen bir hadisin sıhhati bazen de anlamı sorulmaktadır. Hadisle ilgili bu iki konu hem geçmişin hem de bugünün problemidir. Bu çalışmanın amacı da hadis alanında geçmişi anlayarak bugünün sıkıntılarını giderme yolunda bir katkı sunmaktır. İmam Muhammed'e yöneltilen sorular oldukça dikkat çekicidir. Çünkü ona sorulan hadisler günümüz hadis tartışmalarında karşılaştığımız türde hadislerden oluşmaktadır. Bu hadisler insan aklını kurcalayan, Hz. Peygamber'e aidiyetinden şüphe duyulan hadislerdir. İmam Muhammed'e sorulan hadislerden anlaşıldığı kadarıyla o günlerde de rivayet edilen ve insanlar arasında dolaşan hadisler insanların zihinlerini kurcalamakta, onların zihninde problem oluşturmaktadır. Örneğin, imama Hz. Peygamber'in Kur'an âyetlerini unuttuğunu ifade eden hadisin anlamı sorulmaktadır. Bu hadis insanların zihninde soru işaretlerinin oluşmasına ve indirilen Kur'an hakkında acaba bir eksiklik mi var? şeklinde bir şüphe oluşmasına neden olmaktadır. Yine imama İslam fıtratı üzere doğan çocuklarla küfür üzere doğan çocukların durumu, Hz. Peygamber'in ipek elbise giydiğini ifade eden hadis, 'İsrailoğulları olmasaydı et bozulmazdı' hadisinin anlamı sorulur. Bütün bunlar göstermektedir ki hicrî üçüncü asırda insanlar arasında dolaşan rivayetler insanların zihninde problem oluşturmuş, onların akıllarının karışmasına neden olmuştur. Hicri üçüncü asırda imam imam Muhammed'e sorulan bu hadisler bugün de benzer şekilde insanların zihnini kurcalamakta ve çeşitli mahfillerde sorulmakta ve tartışılmaktadır.

O nedenle hicri üçüncü asrın sonları ve dördüncü asrın başlarının âdeta bir fotoğrafını vermesi bakımından hem bu sorular hem de imam Muhammed'in bunlara verdiği cevaplar önem arz etmektedir. Diğer taraftan da hem sorulan hadisler hem de verilen cevaplar günümüz hadis tartışmalarına tarihî bir arka plan sunması bakımından ehemmiyet arz etmektedir. Hadisin hem sıhhati hem de anlamı hakkında cevap verirken imam Muhammed'in özellikle Kur'an'ı ve Hz. Peygamber'in peygamberlik şahsiyetini dikkate alarak hadislerde dile getirilen ifadeleri Kur'an ve Sünnet bütünlüğü çerçevesinden bir değerlendirmeye tabi tutması oldukça dikkat çekicidir. $\mathrm{O}$, hadislerin sıhhatini belirleme konusunda sika ravilerin gözetilmesi gerektiğinin farkındadır. Ancak sika ravilerin rivayetleriyle iktifa etmeyi de yeterli görmemekte, hadislerin metinlerinin en başta Kur'an ile birlikte bir değerlendirmeye tabi tutulmasını gerekli görmektedir. Çünkü, ifadelerinden anlaşıldığı kadarıyla imam Muhammed hadislerin metinlerinde bir takım problemler görmektedir. Bu problemler hadisin belli belirsiz kişiler, zümreler tarafından nakledilmesinden kaynaklanmaktadır. Bu nedenle imam Muhammed'in hadisleri yorumlamasına geçmeden önce onları neden bu şekilde yorumladığını anlayabilmek için onun sünnet ve hadis gerçeğine nasıl baktığını bu iki kavramı nasıl algılayıp tasavvur ettiğini anlamamız gerekmektedir. 


\section{Sünnet ve Hadis'e Bakışı}

Muhammed b. Yahya Kitab ve Sünnet'in dinde asıl olduğunu ifade etmektedir. (Mecmû' I, 202) Ancak bu iki asıl birbirinden bağımsız iki kaynak olmayıp aksine birbiriyle iç içe olan asıllardır. Onun düşünce dünyasında hiçbir zaman sünnet Kur'an'dan ayrı değildir. Çünkü, Hz. Peygamber Allah'ın Kitabı'nın mübelliği ve açıklayıcısıdır. Bu yönü ile sünnet Kur'an'dan bağımsız değil bilakis Kur'an'ın hayata aktarımından ibarettir. Allah'ın kulu ve Resûlü olan Hz. Peygamber'in Allah'ın Kitab'ına aykırı bir şey söylemesi ve yapması mümkün değildir. İmam Muhammed Hz. Peygamber'e itaat edilmesi, onun örnek alınması inancını taşımaktadır. Sünnet, Hz. Peygamber'in Kur'an'ı açıklayıcı mahiyette ortaya koyduğu, Allah'a kulluğun nasıl olması gerektiğinin keyfiyyetini belirlediği örnekliğinden ibarettir. Onun bu örnekliğinin en temel referansı Kur'an'dır. Çünkü o, Kur’an'ın açıklayıcısıdır. Dolayısıyla onun söz ve uygulamalarının Kur'an ile çatışması düşünülemez. Hz. Peygamber'in örnekliği olan sünnetini bize taşıyan da şüphesiz hadislerdir. Ancak imam Muhammed, sünnet konusunda insanlara ona uymalarını öğütlerken benzer şekilde hadisler konusunda da insanları uyarmakta $\mathrm{Hz}$. Peygamber hakkında yalan uyduranların göz ardı edilemeyeceğini dile getirmektedir. Onun bu tavırlarından sünnet ile hadisi birbirinden ayırdığını söyleyebiliriz. Buna göre sünnet $\mathrm{Hz}$. Peygamber'e aidiyeti sabit olmuş ve dinde hüccet olan örnek söz, davranış ve tutumlardır. (Mecmû', II, 607)

Sünnet'in Kur'an'la birlikte, onunla iç içe bir asıl olduğunu kabul eden imam Muhammed bu yaklaşımının tabii bir sonucu olarak Hz. Peygamber'in gerek söz ve gerekse fiillerinin aktarıcısı konumunda olan hadis/haber malzemelerine öncelikle Kur'an nazarından bakmaktadır. O, içeriği Kur'an'ın içeriği ile örtüşen hadisleri kabul etmekte, bunun tam tersi istikamette muhtevası Kur'an'ın muhtevası ile çelişen hadisleri ise reddetmektedir. İmam Muhammed'in hadislere Kur'an nazarından bakması Hz. Peygamber'in sünnetinin sadece Kur'an'la iç içe olması ilkesinden kaynaklanmamaktadır. Diğer taraftan o, tarihî bir olgunun farkındadır ve $\mathrm{Hz}$. Peygamber'den nakledilen hadisler karşııında bu farkındalıkla hareket etmektedir. İmam Muhammed'e göre Kur'an'a aykııı olan çok sayıda hadis bulunmaktadır. Çünkü din düşmanları daha önceki peygamberler hakkında iftiralarda bulundukları gibi $\mathrm{Hz}$. Peygamber hakkında da iftiralarda bulunmuş, onun söylemediği sözleri o söylemiş gibi nakletmiş, onun yapmadığı işleri de sanki peygamber yapmış gibi aktarmışlardır. Nesilden nesile mütevatir yolla aktarılan ve en önemlisi Hz. Peygamber döneminde onun talimatı ve gözetimiyle resmî olarak yazıya geçirilen Kur'an üzerinde herhangi bir manipülasyon gerçekleştiremeyen din düşmanları emellerini hadisler üzerinden gerçekleştirmeyi hedeflemişlerdir. Bu gerçek bizzat Hz. Peygamber tarafından ifade edilmiş ve $\mathrm{Hz}$. Peygamber ümmetini hadisler konusunda daha dikkatli ve hassas olma noktasında uyarmıştır. Hz. Peygamber ümmetine bu noktada Kur'an'ı adeta hakem olarak kullanmalarını öğütlemiş ve buyurmuştur ki "Benden önceki peygamberler hakkında yalanlar söylendiği gibi benim hakkımda da yalan açıklamalar yapılacaktır. Benden olduğu iddia edilen bir söz size ulaştığında onu Allah'ın Kitabı́na arz edin. Şayet o söz Allah'ın Kitabı'nın içeriğine muvafık ise o bendendir onu ben söylemişimdir. Şayet bana izafe edilen söz Allah'ın Kitabı'na aykırı ise o benden değildir, onu ben söylememişimdir." Bu hadis bazıları 
tarafından zayıf kabul edilse de çoğu alim ve fakih tarafından da kabul edilmiştir. ${ }^{1}$ Arz hadisi diye adlandırılan bu hadis Zeydiyye mezhebi imamları tarafından da özellikle kabul edilmiş ve hadis tenkit ve yorumunda kriter olarak kullanılmıştır. Çünkü Zeydiyye mezhebinin imamı Zeyd b. Ali (ö.122/740) kendisine hadisler konusunda nasıl hareket edeceğiz sorusunu yöneltenlere bu hadisi hatırlatmış ve hadislerin Kur'an'a arz edilmesi gerektiğini ifade etmiştir. İmam Zeyd'in bu tavrından itibaren Zeydiyye içerisinde arz hadisi sahih kabul edilmiş ve Zeydî imamlar hadisleri değerlendirmede onları öncelikle Allah'ın Kitabı'na arz etmek suretiyle sıhhatları hakkında bir değerlendirmede bulunmuştur. Aynı tutum imam Zeyd’den sonra Kasım er-Ressî (ö.246/860) de (Ümit, 2018: 124) onun torunu imam Hadi ile'l-Hak Yahya b. el-Hüseyin'de (ö.298/911) (Ümit, 2018: 124) daha sonra Muhammed b. Yahya'da (ö.310/923) ve Nâsıru'ddin el-Utruş (ö.304/917) da devam etmiştir. Dolayısıyla Zeydiyye mezhebinde hadisler konusunda imam Zeyd'den itibaren başlayıp devam eden bir hassasiyet gelenek haline gelmiş ve nesilden nesile devam etmiştir. (Demirci, 2012: 30-70)

İmam Muhammed b. Yahya'ya göre Peygamberlerden ve imamlardan birbiriyle çelişen, birbiriyle farklıık arz eden haberler nakledilmiştir. Bu tür haberler, hükümler hakkında Peygamberlerin Allah'tan getirdikleri hükümleri bozduklarını, onun şeriatını değiştirdiklerini söylemek asla mümkün değildir. Hiçbir mümin böyle bir şey söyleyemez. Çünkü, böyle bir şey söylemek, hatta bunu hatırından geçirmek bir mümine caiz değildir. Öyle ise hadislerde görülen ihtilaflar, çelişkili ifadeler nereden kaynaklanmaktadır? İmam Muhammed'e göre söz konusu ihtilaflar, çelişkiler, Peygamberden değil onları nakleden ravilerden kaynaklanmaktadır. (Mecmu' I, 204) Ona göre özellikle ashab-ı hadis rivayetler konusunda gevşek davranmış, hadisleri ciddî bir tenkide tabi tutmamıştır. İmam Muhammed'in ifadelerinden anlaşıldığı üzere ashab-ı hadis özellikle hadislerin içerikleri konusundaki tenkidi çokça inmal etmiştir. Bunun neticesinde de tuhaf, izah edilmesi zor rivayetleri nakletmekten kurtulamamışlardır. Bu nedenle imam Muhammed'in hadise bakışında ashab-ı hadis olgusu dikkat çekmektedir. Çünkü ona göre ashab-ı hadis hadis rivayet ederken hadislere ilaveler, ziyadeler, yapmış, bazı bidatleri hadisler yoluyla yaymaya çalışmıştır. Ayrıca ona göre hadislerde cahil kişilerin acayip, tuhaf, akıl almaz, faydasız sözleri de yer almaktadır. (Mecmu', II, 617, 619)

İmam Muhammed Hz. Peygamber'in sünnetini önemsemektedir. Ancak bu, onun sünneti temsil adı altında hadis diye nakledilen her bir rivayeti kabul edeceği anlamına gelmemektedir. $\mathrm{O}$, hadisin raviler tarafından nakledildiğinin ve birer insan olan ravilerin de yanılabileceğinin, beşer olmaları hasebiyle yanlışlıklar yapabileceklerinin son derece farkındadır. Bu nedenle hadiste rivayet esnasında düşen, unutulan, raviler tarafından çıkartılan, bazen hatalı şekilde nakledilen, Arap diline uymayan, arap dilinde bilinmeyen, kullanılmayan kelimeler bulunduğunu ifade etmektedir. (Mec-

\footnotetext{
${ }^{1}$ Arz hadisi diye isimlendirilen bu hadis hakkında yapılan bir doktora çalışması için bkz: Ahmet Keleş, Hadislerin Kur'an'a Arzı, İnsan Yayınları, 1998. Ayrıca bu hadis hakkında çalışma yapan zeydî âlim Muhammed Yahya Salim Azzan'ın Arzu'I-Hadis ale'I-Kur'an adlı çalışmasına bakılabilir. Muhammed Yahya bu çalışmasında arz hadisinin pek çok mezhebe göre sahih olduğunu dile getirmekte ve bunların delillerini ortaya koymaktadır.
} 
mu', I, 101, 104, 154) İmam Muhammed'e göre hadislerde yer alan bu ve buna benzer yanlışlıklar yanında zaman zaman kasıtlı yapılan ilaveler, araya sokuşturulan kelimeler de yer almaktadır. Örneğin, İmam Muhammed'e göre âmmeden bazıları, şahitliği kabul edilemeyecek olanların sayıldığı hadisin içine akrabanın şahitliğini de kabul edilmeyenler içinde olduğunu eklemişlerdir. (Mecmu' I, 125) Ayrıca hadislerde ashab-ı hadisin ziyadeleri bulunmakta; manası bilinmeyen kelimeler yer almaktadır. (Mecmu' II, 601, 607, 617)

Ravilerde görülen bu gibi durumlardan dolayı imam Muhammed hadisleri nakledenlerin âlim kişiler olmasına ihtimam gösterir. Onun ifadelerinden anlaşıldığı kadarıyla cahil kişiler rivayet ettiklerinin içerikleri konusunda bir bilince sahip olmayıp, tam tersine her duyduklarını rivayet edebilecek bir gevşeklik içindedirler. Bu nedenle imam Muhammed âlim olmayan, cahil kişilerin rivayetlerini eleştirir. $\mathrm{O}, \mathrm{Hz}$. Peygamber'in nübüvvet pınarından çıkan hikmetli sözleriyle cahillerin ağzından çıkan hikmetsiz sözleri ayırt edebilecek bir bilinç geliştirmiştir. Dolayısıyla hadislerin içerikleri üzerinde de son derece şuurlu, dikkatli hareket etmektedir. O, İslam tarihinde ortaya çıkan fırkaların ve bunların kendi görüşlerini desteklemek maksadıyla hadisler uydurduklarının da bilincindedir. Bu nedenle fırkaların görüş ve düşüncelerini bilmekte ve hangi hadisin hangi fırka tarafından uydurulmuş olabileceğini anlayabilmektedir. Örneğin, Müşebbihe İslam inancına aykırı rivayetlerde bulunmuştur. İmam Muhammed bir hadisin içeriğinden hareketle onun Müşebbihe'nin uydurduğu bir hadis olduğu hükmünü verebilmektedir. (Mecmu', II, 621) Ayrıca olur olmaz rivayetleri nakleden, rivayet ettikleri hadisler üzerinde düşünmeyen, dikkatli ve hassas olmayan hadis taraftarları içerisinde özellikle Haşeviyye olgusuna dikkat çeker. Haşeviyye'den gelen batıl rivayetleri tespit etmede hassas davranır. (Mecmu' II, 607) İmam Muhammed özellikle ashab-ı hadisin hadis rivayetindeki gevşekliğine dikkat çekmek için onların acâib, tuhaf rivayetlerde bulunduklarını dile getirir. Mesela o zaman zaman "bu hadis ashab-ı hadisin bidatlerindendir" der. (Mecmu' II, 617, 619)

İmam Muhammed'in hadis konusundaki bu bakışı onun karşılaştığı bir hadise yaklaşımında son derece etkili olmuştur. $\mathrm{O}$, kendisine sorulan bir hadisin hem sıhhatini belirlemede hem de onu yorumlamada hadisle ilgili bütün bu problemleri dikkate alarak hareket etmektedir. Hadisleri nakleden ravilerin sika olmasını önemser, ancak sikanın rivayetine de bütünüyle teslim olmaz. Hadisin ihtiva ettiği anlam en başta Kur'an, daha sonra üzerinde icma edilmiş olan sünnet ve akıl ile uyum halinde olmalıdır. Hadisin sıhhatini belirlemede bu şekilde bir yaklaşım sergileyen imam Muhammed'in bu yaklaşımını biraz daha ayrıntılı bir şekilde görebiliriz.

\section{Hadis Tespit Yöntemi}

İmam Muhammed'in eserlerinde dikkat çeken yönlerden birisi onun hadis kaynaklarına atıfta bulunmamasıdır. Halbuki yaşadığı hicrî üçüncü asrın son çeyreği temel hadis kaynaklarının yazıldığı bir dönemdir. Bu durum özellikle sonradan Kütüb-i Sitte diye meşhur olan altı hadis kitabının daha üçüncü asrın sonlarında yaygınlık kazanmadığı şeklinde değerlendirilebilir. Ancak bu altı hadis kitabından çok daha önce telif edilmiş olan örneğin sünnetin beşiği olarak bilinen Medine'nin imamı Malik b. Enes'in (ö.179/795) Muvatta'ına da imam Muhammed'in eserlerinde herhangi bir atıf yapılmamaktadır. Benzer şekilde Yemenli hadis müellifleri Mamer b. Raşid'in (ö.153/770) ve 
Abdurrezzak'ın (ö.211/827) eserleri de aynı şekilde onun eserlerinde zikredilmemektedir. Bu muhaddisler imam Muhammed'in mensubu olduğu ehl-i beyt çizgisinin dışında olan müellifler olması sebebiyle kendilerine atıf yapılmamış, eserleri de kullanılmamıştır denilebilir. Ancak imam Muhammed'in ait olduğu çizginin hadis eseri olan imam Zeyd'in (ö.122/740) Müsned'ine ya da elMecmû'u'l Hadisi veya fıkhına da hiçbir şekilde atıf yapılmamaktadır. Yine Buhari ile çağdaş olan ve kaleme aldığı eseri sonradan Zeydiyye'nin Buhari'si olarak anılan Ahmed b. İsa'nın (ö.246) elEmâli'si de imam Muhammed'in eserlerinde hadis tespiti için hiçbir şekilde anılmamaktadır. Belki bu durum da büyük bir baskı altında yaşayan Zeydilerin birbirleriyle rahat bir şekilde irtibat kuramamalarından kaynaklanmıs olabilir diye yorumlanabilir. Ya da daha çok soru ve cevap formunda bir muhtevaya sahip olan imam Muhammed'in eserlerinin kaleme alınş tarzından kaynaklanan bir durum da olmuş olabilir. Daha çok kendisine sorulan sorulara cevap vererek pratik ihtiyaçları karşılayan imam kısa cevaplarıyla kendisinden önce yazılmıs olan hadis kaynaklarına atıf yapmamıştır denilebilir. Denilebilecek başka bir şey daha vardır o da, imam Muhammed'in bu eserlerden ya da müelliflerinin rivayet ettikleri hadislerden haberdar olmamasıdır. Bunu söylemek zordur. Çünkü o, sık sık başkalarının rivayet ettiği hadislere atıflar yapmaktadır. Bu atıflar onun kendi yanında sahih olarak mahfuz bulunan rivayetler dışında var olan ve nakledilen hadislere vakıf olduğunu göstermektedir. Gerekçe ne olursa olsun onun eserlerinde görülen manzara budur. O, zaman zaman gerek duyduğunda babası imam Hadi Yahya b. Hüseyin'e büyük dedesi Kasım er-Ressîye atıflar yapar. Ancak Sünnî ve Zeydî temel hadis kaynakları olarak bilinen eserlere hiçbir atıfta bulunmaz. Peki imam Muhammed kendisine sorulan hadisler konusunda nereye atıfta bulunur?

İmam Muhammed kendisine sorulan hadisler konusunda sık sık kendi hadis birikimine atıfta bulunur. Bu durum onun da bir muhaddis olduğunun göstergesidir. İfadelerinden anlaşıldığına göre o, ciddi bir hadis birikimine sahiptir. Bu birikim, özellikle ehl-i beyt ravileri tarafından nakledilmiş ve en önemlisi alim kişiler tarafından aktarılmış, $\mathrm{Hz}$. Peygamber'e aidiyeti konusunda maruf ve meşhur olan hadislerden oluşmaktadır. İmam Muhammed en başta babası Yahya b. el-Hüseyin tarafından nakledilen hadislere vakıftır. Onun vasıtasıyla büyük dedesi Kasım er-Ressî kanalıyla Hz. Ali'den gelen hadis birikimine sahip olduğu anlaşılmaktadır. İmam Muhammed sahâbi raviler arasında Hz. Ali'den gelenleri diğer sahabilerden gelenlere tercih etmektedir. Çünkü ona göre $\mathrm{Hz}$. Ali, $\mathrm{Hz}$. Peygamber'e tanıklık etmiş, her daim onun yanında bulunmuş, ilim, fazilet ehli olup, helali ve haramı da en iyi bilendir. (Mecmu' I, 225) Ancak bu durum onun, Hz. Ali'den gelen rivayetleri mutlak anlamda kabul ettiği şeklinde anlaşılmamalıdır. Çünkü o, Hz. Peygamber hakkında yalan üretildiğinin farkında olduğu gibi $\mathrm{Hz}$. Ali hakkında da yalan haber oluşturulduğunun bilincindedir. Özellikle muhtevası Kur'an'la çelişen bir hadis, ister Hz. Ali tarafından gelmiş olsun ister başka ehl-i beyt imamları tarafından rivayet edilmiş olsun imam Muhammed tarafından sahih nitelemesini hak edemez. Onun hem ezberinde hem de yazılı nüshalarda mevcut bulunan hadisler güvenilir sika ravilere ve Kur'an'ın muhtevasına uygun olan hadislerden oluşmaktadır. Kendisine bir hadis sorulduğunda öncelikle o hadisi bilip bilmediğini, duyup duymadığını kendi zabtında yer alıp almadığını ifade etmektedir. Bu tür hadisler hakkında o şöyle ifadeler kullanır: 
-la nahfazu an Rasulillah fi zalike nehyen vela kerâhiyeten.. "Bu konuda Rasulullah'ın bir yasağını tespit etmedik" (Mecmu' I, 94)

-la nesmeu, ma semi'na.. "Rasulullah'dan böyle bir hadis işitmedik, duymadık"

-haze'I-hadis la na'rifu vela nervîhi anhu sallallahu aleyhi ve sellem "Rasulullah'tan aktarılan bu hadis bizim bilmediğimiz ve rivayet etmediğimiz bir hadistir" (Mecmu' I, 95, 104)

-lem yusma' haza'I-hadis anhu ...vela na'rifuhu.. “Bu hadis Rasulullah'tan duyulmamış ve bizim bilmediğimiz bir rivayettir" (Mecmu' I, 107)

-ve kad semi'na fi zikri's-saati ahbâran leyse haza minha "Kıyamet saati ile ilgili pek çok haber vardır ama bu hadis onlardan değildir"' (Mecmu' I, 107)

-lem nes'ma' bihi ani'n-Nebiyy sallallahu aleyhi ve sellem.. "Biz bu hadisi $\mathrm{Hz}$. Peygamber'den işitmedik" (Mecmu' I, 123)

Birkaç örnekle yetindiğimiz bu ve buna benzer ifadeler daha önce belirttiğimiz gibi imam Muhammed'in müktesebatında var olan bir hadis repertuarına işaret etmektedir. Bu repertuar alimler arasında maruf, meşhur, yaygın hadislerden oluşmaktadır. Bu hadisler içerik olarak da Kur'an ile örtüşen, onunla çelişmeyen, güvenilir ravilerden nakledilen hadislerdir. İmam Muhammed öncelikle kendisine sorulan hadisi bu repertuarı açısından bir değerlendirmeye tabi tutar ve yukarıda işaret edildiği gibi ifadeler kullanır. Dolayısıyla onun hadis kaynağı olarak zikrettiği kendi müktesebatı, hocalarından aldığı kendi rivayetleridir. Bu yönüyle onun bir muhaddis olduğunu söyleyebiliriz. Ancak o, bir muhaddis gibi hadisleri senediyle nakletme cihetine gitmemektedir. Bununla birlikte onun mahfûzâtında bulunan hadislerin senedinin bir aile isnadı olduğunu söyleyebiliriz. Zaten kendisi de bunu dile getirmektedir. İmam Muhammed'in, kendisine sorulan hadisin tespiti konusunda öncelikle kendi müktesebatıyla o rivayeti karşılaştırdığı anlaşılmaktadır. O, repertuarında olmayan bir hadisi hemen reddetme cihetine gitmez. Hadis hakkında 'eğer sahih ise', 'eğer hak' ise Rasulullah şunu murat etmiştir gibi yorumlar yapar. Ancak çoğunlukla da hadisin kendi repertuarında olmadığını ifade etmek şeklinde kısa cevapla yetinir. Ya da hadis hakkında şayet bir bilgisi varsa onu dile getirmekten geri kalmaz. Mesela der ki "bu hadis avam insanların dilinde dolaşan bir sözdür". İmam Muhammed'e göre bir hadis sahih ise o alimler tarafından bilinir. İmam Muhammed'e göre sahih bu anlamda bilinen, tanınan, maruf olan hadis demektir. $\mathrm{O}$, alim kişiliği ile ulema nezdinde maruf olan kimseler tarafından rivayet edilen, kullanılan, kabul edilen, bilinen hadislere iltifat eder. Bunun dışında ulemanın bilmediği, az rivayet edilen ve de faydadan hali olan rivayetlere ise iltifat etmediği gibi başkalarına da bu gibi hadislere iltifat etmemelerini öğütler. (Mecmu', I, 111)

İmam Muhammed hadislerin Hz. Peygamber'e aidiyetini tespit hususunda bir önceki başlıkta dile getirilen hadisle ilgili düşüncesi, hadise bakışı belirleyicidir. $O$, raviler tarafından nakledilen hadise onun aktarımında gerçekleşmiş olan bütün problemleri dikkate alarak eleştirel bir şekilde yaklaşır. Hadis gerçeğinin bir nakilden ibaret olduğunun ve nakil süreci içinde bir çok problemlerin hadise bulaştığının bilincindedir. Tabi ki en önemlisi hadis kullanılarak Hz. Peygamber hakkında yalan söylendiğinin son derece farkındadır. Hz. Peygamber hakkında söylenen yalan onun nazarın- 
da sadece din düşmanlarının yaptıkları bir şey değildir. Müslüman olduğunu dile getiren ancak farklı bir inanç ve yol benimsemiş kişiler ya da insanî zaafları olanların da hadis uydurma faaliyetinden hiç de geri kalmadıklarının farkındadır. Bu nedenle o, hadisteki uydurmacılığa karşı önemli derecede bir bilinç geliştirmiştir. Hadis uydurma, din düşmanlarının kullandığı bir yoldur. Çünkü Kur’an'ı Kerim'e karşı onun anlamını değiştirmenin dışında yapılabilecek bir olumsuzluk söz konusu değildir. Hz. Peygamber tarafından resmî kayıt altına alınmış ve büyük bir kitle tarafından ezberlenmiş bir Kur'an-ı Kerim bulunmaktadır. Ancak hadisler böyle değildir. İşte bu durumun farkında olan din düşmanları ya da İslam dairesi içinde olan ancak ait oldukları inanç ve düşünce taassubunun etkisinden kurtulamayanlar Kur'an'a aykırı anlamda hadis uydurmuşlardır. Bu uydurmaları tespit etmenin en sağlam, en kestirme ve de hızlı yolu hadislerin içeriklerini Kur'an ile mukayese ederek değerlendirmektir. İşte imam Muhammed bu sağlam ve hızı yolu, hadisleri tespit etmede en başta gelen bir kriter olarak kullanır. Zaten o nakledilen hadislerden pek çoğunun Kur'an’a aykırı olduğu şeklinde bir kanaate sahiptir. Bu kanaat sebebiyle hadislere hep Kur'an nazarından bakmayı öncelikli bir yol olarak görür. Bu nedenle Hz. Peygamber'e nispet edilen hadislerin sıhhati konusunda imam Muhammed'in en dikkat çeken yöntemi hadisin içeriğini Kur'an'ın içeriği ile birlikte ele almasıdır. O, kendi kullandığı tabir ile Kur'an'ı hadisin sıhhatini tespit konusunda 'şahit' ve 'musaddık' olarak değerlendirir. Bunun dışında hadis Hz. Peygamber'in sireti ile de çatışmamalı, çok bilinen sünneti ile de aykırılık arz etmemelidir. Bunların dışında ona göre hadisi âlim rivayet etmelidir. Ayrıca hadisin bir aslı, dayanağı olmalı ve dahi hadis sika bir ravi tarafından nakledilmelidir. Onun bu konudaki cümleleri şu şekildedir: "Enne külle hadis an Rasulillah sallallahu aleyhi ve sellem feinnehu gayru muhalif lilkitab, bel el-Kitab yeşhedu aleyhi bi'l-hakk ve yentıku fihi bi's-sıdkı" (Mecmu' I, 89, II, 509, 601) “Gerçekten Rasulullah'dan gelen hadislerin hiçbiri Kur'an'a muhalif değildir; bilakis Kur'an bu hadislerin hak olduğuna onların doğruyu ifade ettiğine şahitlik eder."

İmam Muhammed'in eserlerinde hadis kaynaklarına her hangi bir atıf yapılmadan hadislerin nakledilmesi o dönemde hadis kaynaklarının en azından Zeydiyye cephesinde yaygınlık kazanmadığını gösterdiği gibi aynı zamanda hadis kaynaklarının hadislerin sıhhatini değerlendirmede bir kriter olarak kullanılmadığını da işaret edebilir. İmam Muhammed dînî bilginin sahih, sağlam bir temele dayanması gerektiği kanaatindedir. Aksi halde din bidatlere dönüşür. Dini bilginin dayandığı iki asıl vardır. Biri Allah'ın Kitab’ı Kur'an diğeri Hz. Peygamber'in Sünnet'idir. Sünnet de Kur'an'dan bağımsız bir kaynak değildir. Dolayısıyla Hz. Peygamber'e ait olduğu iddiasıyla nakledilen hadislerin gerçekten Hz. Peygamber'e olan aidiyetini tespit edebilmek için dinin en temel kaynağı olan Kur'an'a ve onunla paralellik arz eden sünnete bakmak gerekmektedir. Bu iki kaynak mukayesesi ile hadislerin sıhhati belirlenmelidir. Imam Muhammed hadislerin tespitinde bu yolu kullanmaktadır. Ancak bu yolun da sorunsuz olduğu hiç şüphesiz söylenemez. Öncelikle hem Kur'an'ın hem de Sünnet'in çok iyi bir şekilde bilinmesi, hatta bilinmeden öte bu iki kaynak üzerinde derin bir vukûfiyet elde edilmesi gerekmektedir. 
Acaba imam Muhammed tespit edilen hadisleri nasıl yorumlamaktadır? Yorumlamada takip ettiği bir yöntem bulunmakta mıdır? Ya da bir yöntemden önce hadisleri anlama ve yorumlamada nasıl bir yaklaşım sergilemektedir? Bu sorular ileri başlıklarda cevaplanmaya çalışılacaktır. Ancak öncelikle imam Muhammed'in hadis yorumunda ısrarla kullandığı bir terminoloji, kavram ya da kavramlar bulunmakta mıdır? Şimdi bu sorunun cevabı üzerinde biraz duralım.

\section{Hadis Yorumunda Kullandığı Kelimeler}

İmam Muhammed hadisi yorumlarken bazen tefsir, bazen tevil kelimelerini kullanmakta, bazen 'erade Rasulullah' ifadesine yer vermekte, bazen 'ma'ne'l-hadis' diyerek bir açıklama yapmaktadır. Onun, tefsir kelimesi ile daha ziyade hadisin anlamının şerh edilmesini kastettiği anlaşılmaktadır. Tevil kelimesi ile zahirde anlaşılmayan, anlamı kapalı olan bir hadisi anlaşılabilir başka bir manaya hamletmeyi kastetmektedir. (Mecmu' I, 93)

İmam Muhammed'in hadisi anlamlandırırken kullandığı ifadelerden bazıları şu şekildedir:

-"ve lehu tefsir"... "Bu hadisin bir açıklaması vardır" (Mecmu' I, 93)

-"erade sallallahu aleyhi ve sellem”.. “Hz. Peygamber bu hadiste şunu murat etti” (Mecmu' I, 93)

-“ma'na'I-hadis".. "Hadisin anlamı şudur" (Mecmu' I, 103)

-"ve't-tevilu".. "Hadis şu anlama hamledilebilir" (Mecmu' I, 103)

-"ve'l-ma'ne'l-evvel asvab ve ahsen fi't-te'vil".. "Hadis için ilk verdiğimiz anlam en doğrusu ve yapılan tevil de en güzelidir" (Mecmu' I, 107)

-"in kane'l-hadis sahihan feinnema yahrucu ma zekerna mine't-te'vil”.. "Eğer hadis sahih ise ondan zikrettiğimiz şu anlam çıkar" (Mecmu' I, 144)

İmam Muhammed'in hadis yorumunda değişik kelimeler kullandığı görülmektedir. Ancak bu kelimelerin çok gelişmiş, birbirinden ayrı tutulmuş bir yanları olduğunu söylemek zordur. Onun bu kelimeler içerisinde tevil kelimesini biraz farklı kullandığı söylenebilir. O tevil kelimesini, hadisin lafzında kapalı olan, anlaşılmayan bir ifadeyi makbul bir anlama hamletme olarak kullanmaktadır. Hadislerin anlaşılması ve yorumlanması ile ilgili kavramlar zeydî literatüründe görebildiğimiz kadarıyla Ahmed b. Süleyman'da (ö.566/1176) daha bir yaygın ve sistematik bir hal almıştır. ${ }^{2}$

\footnotetext{
${ }^{2}$ Bu konuda geniş bilgi için bkz: Kadir Demirci, "Zeydî Hadis Yorumu: İmam el-Mütevekkil Ale'llah Ahmed b. Süleyman Örneği” e-Şarkiyat IIImi Araştırma Dergisi, 2018, cilt: X, sayı: 20, s. 524-547)
} 
Kadir DEMIRCi

\section{Hadis Yorumunun Dayanakları}

\subsection{Kur'an'ın Şahitliği}

İmam Muhammed her hangi bir hadisi yorumlayacağında Kur'an'ın içeriğini mutlaka dikkate alır ve hadisi Kur'an'da yer alan anlama uygun olacak şekilde yorumlar. Şayet Kur'an'da yer alan anlam ile hadis çelişiyor ise ya da hadiste Kur'an'da olandan farklı bir durum var ise, o takdirde hadisi ya reddeder ya da hadise ilaveler yapıldığı yorumunu yapar. Çünkü ona göre temel ilke şudur: Hz. Peygamber asla Allah'ın Kitab'ına aykırı bir şey söylemez ve yapmaz. O, Peygamber'den Allah'ın Kitab'ı ile çelişen, ona aykırı olan bir hadis nakledildiğinde söz konusu rivayetin uydurulduğunu ifade eder. Ona göre Kur’an'a aykırı pek çok rivayet bulunmaktadır. Uydurulan şey bazen toptan bir hadis şeklinde olabileceği gibi sahih bir hadisin içinde bazı kelimeleri ilave etme şeklinde de olabilmektedir. Örneğin, Kur'an okumaya başlamadan önce söylenilmesi gereken istiâze konusuyla ilgili rivayet karşısında imam Muhammed'in bu tavrını görmek mümkündür. Hadiste Kur'an okumaya başlamadan önce şu şekilde bir istiâze yapılması ifade edilmektedir: "Eûzu billahi mine'şşeytani min nefhıhi ve nefesihi". İmam Muhammed bu istiâzeyi kabul etmez, burada yer alan 'nefh' ve 'nefes' kelimelerinin ashab-ı hadis tarafından hadise ilave edildiği yorumunu yapar ve Kur'an'da geçen şu âyetin istiâze olarak yapılması gerektiğini söyler. "Kur'an okuduğunda rahmetten tarh edilmiş olan şeytandan Allah'a sığın”. (Nahl, 16:98; Mecmu', II, 603)

İmam Muhammed'e Rasulullah tarafından başın toptan traş edilmesinin yasaklandığı şeklinde bir bilginin doğru olup olmadığı sorulur. İmam bu konu ile ilgili olarak her zaman ki gibi yine rivayet kaynağına ya da isnadına atıf yapmadan Kur'an'ı delil getirerek böyle bir yasağın Rasulullah tarafından olamayacağını söyleyerek cevap verir. Çünkü Allah Teâlâ Kur'an'da şöyle buyurmuştur: “Siz Mescid-i Harama saçlarınızı toptan traş etmiş ya da kısaltmış bir şekilde gireceksiniz" (Fetih, 48: 27) İmam Muhammed bu ayeti dile getirdikten sonra şu soruyu sorar: "Allah'ın izin verdiği, mübah kıldığı bir şeyi Rasulullah nasıl olur da yasaklar?" (Mecmu', I, 94)

İmam Muhammed'in hadisleri yorumlarken Kur'an'ın şahitliğine müracaat ettiğini gösteren örneklerden bir diğeri de şudur:Müslim'de geçen ve Allah'ın kullarını Hanifler olarak yarattı̆̆ını ancak sonradan onları şeytanın saptırdığını ifade eden hadis sorulur. $\mathrm{O}$, bu hadisin anlamı karşısında da bir ayet dile getirerek, hadiste ifade edilen anlamın bozukluğuna işaret eder ve Allah kullarını kendisine itaat etmesi ve yasakladığı şeylerden de kaçınmaları için yaratmıştır der. (Mecmu' II, 594, 595)

İmam Muhammed'e cennete en son giren kişinin durumunun anlatıldığı bir hadis sorulur. Uzunca olan bu hadise göre "kişi sırat üzerinde yürür, sonra yüz üstü yere kapanır. Sonra kalkar tekrar biraz daha yürür bu sırada cehennem ateşi onun üzerine doğru gelir. Nihayet kul sıratı geçer. Başını kaldırdığında bir ağaç görür ve der ki Ya Rabbi! Şu ağacı bana yaklaştırsan da gölgesinden yararlansam..." (Musannef, K.Cennet, hno: 33319) İmam Muhammed bu hadisin Hz. Peygamber'den nakledilmesinin batıl olduğunu söyler. Ona göre bu hadis Haşeviyye'nin ve batıl ehlinin rivayetlerindendir. Çünkü ahirette gölgesinden istifade edilecek bir güneş yoktur. Ahiret nur diyarı- 
dır. Güneş Allah Teala'nın haber verdiği üzere yok olacaktır. Nitekim “Güneş dürülüp karardığında” (Tekvir, 81: 1) ayetinde güneşin bu durumu haber verilmiştir. Tekvir kelimesi güneşin fani olacağına işarettir. İmam Muhammed muhatabına bu gibi uydurulmuş hadislere, çelişkili sözlere iltifat etmemesini söyler. “Çünkü bu tür rivayetler kalbi kör eder, Kitab’a muhaliftir. Kur’an böyle rivayetleri yalanlar ve bunların batıl olduğuna şahitlik eder. Bu gibi sahih olmayan hadislerle kendini meşgul edersen anlayışın kaybolduğu, aklın hayrete kapıldığı derin deryalara düşersin." (Mecmû', II, 607)

İmam Muhammed'e üç evladını kaybeden kişiye cehennem ateşinin dokunmayacağını ifade eden hadis sorulur. (Buhari, Eyman ve'n-nüzûr, 9, 6280) İmam bu hadisin Hz. Peygamber'den geldiğini bilmediğini ifade eder ve devamında şu yorumu yapar. Bir müminin evladı ölür de kişi Allah'ın emrine teslimiyet, hükmüne rıza gösterirse bundan dolayı bir mükafat alır, ecre nail olur. Nitekim Allah Teala şöyle buyurmuştur: "Sabredenler o kimselerdir ki onların başına bir musibet geldiğinde 'Biz Allah'dan geldik ve yine ona döneceğiz' derler. İşte bunlara Rablerinden rahmet ve mağfiret vardır ve onlar hidayet üzere olanlardır”. (Bakara, 2:156, 157) İmam Muhammed konu ile ilgili yorumunu şöyle devam ettirir. Mümin kişi çocuğu ölse de ölmese de ateşin kendisine dokunacağı hallerle karşılaşabilir. Ifadelerinden ve yaptığı yorumdan anlaşıldığı kadarıyla bu hadislerin zahiri şekliyle anlaşımasını yanlış bulmaktadır. Hadisin lafızlarında geçen "Üç çocuğu ölene ateş dokunmaz" ifadesini kabul etmemekte ona bir yorum getirmektedir. Çünkü bir müminin çocuğunun ölmesi ona ateşin dokunmayacağı anlamına gelmez. Esas olan müminin karşılaştığı bu acı karşısında imanına bağlı olarak gösterdiği tavırdır. Nitekim imam Muhammed de buna işaret eder ve kişi Allah'ın emrine teslimiyet, hükmüne rıza gösterirse kaydını yapmak suretiyle konuya bir açıklık getirir. Ayrıca yine bu teslimiyet ve rıza da kişinin ateşte yanmayacağı şeklinde yorumlanmaz. Mümin kişi bu teslimiyet ve rızasının ecrini alır. Ancak müminin kendisine ateşin dokunacağı başka halleri ve durumları olabilir. Dolayısıyla onun bu yorumu ile tek bir olay üzerine bir kulun akıbetinin belirlenmediğini kişinin hesap günü bütünüyle hayatının dikkate alınacağını ifade etmek istediğini söyleyebiliriz. (Mecmû' II, 593)

\subsection{Başka Sahih Hadisi Tercih Etmesi}

İmam Muhammed bir hadisi yorumlarken kullandığı kriterlerden biri de o konu ile ilgili başka hadislerdir. $\mathrm{O}$, kendince sahih kabul ettiği bir hadisi esas alarak başka bir hadisi ya reddetmekte ya da onun anlamı ile ilgili bir yorum yapmaktadır. Örneğin duha namazı ile ilgili soru sorduklarında rivayet edilen hadisi bilmediğini ifade etmektedir. Bu ifade son derece önemlidir. Çünkü bilindiği gibi Müslim, kitabına üzerinde icma edilen hadisleri almıştır. Burada ise Müslim'de yer alan bir hadisi bilmediğini ifade etmektedir. Demek ki Müslim'in icma ile kastettiği bizim genel geçer şekilde bildiğimiz bütün alimlerin üzerinde ittifak edip kabul ettiği anlamında değildir. Çünkü imam Muhammed kendi kabul etmese de âmme tarafından rivayet edilen hadislerden haberdardır ve bunları dile getirmektedir. Müslim'de yer alan duha namazı ile ilgili bir hadisi bilmemesi bu yüzden oldukça önemlidir. Muhtemelen Müslim'deki hadislerin bilinilirlik özelliği de hicrî üçüncü asrın son çeyreğinde çok sınırıdır. İmam Muhammed duha namazı ile ilgili hadise Hz. Peygamber'in o vakitte namaz kılmayı yasakladığını ifade eden başka bir rivayet ile karşı çıkmış ve hadisi kabul etmemiştir. (Mecmu' II, 596, 597) 
İmam Muhammed, İslam fitratı üzere doğan bir çocuk ile küfür fitratı üzerine doğan bir çocuğun hangisinin daha faziletli olduğu sorusuna şöyle cevap verir: Allah Teâla bütün mahlukatı kendisine itaat için yaratmış ve onlar hakkında "Ben cinleri ve insanları ancak bana kulluk etsinler diye yarattım" (Zâriyât, 51: 56) buyurmuşken müşriklerin çocukları için onlar küfür fitratı üzerine doğmuşlardır denilemez. Bundan dolayı her doğan İslam fitratı üzere doğmaktadır. Nitekim Rasulullah da bu hususta şöyle buyurmuştur: Her doğan İslam fitratı üzere doğar. Ta ki onu anne ve babası ya Yahudi ya da Hıristiyan yapar." (Buhari, Cenâiz, 92)

İmam Muhammed'e göre bütün çocukların durumu birdir. Ölen tüm çocuklar cennete gider. Çünkü çocuklar günahsızdır. Onlar emir ve yasaktan sorumlu olacakları yaşa ulaşmamışlardır ki isyan ettiklerinde kendilerine bir ceza verilsin. Allah asla kullarına zulmetmez. Böyle olunca da çocuklar rahmet ve merhamete müstahaktırlar. Allah'ın adaleti budur. Günahı olmayana ceza vermek zulümdür. Allah ise zulümden beridir. $O$, şânı çok yüce ve çok büyük olandır.". (Mecmû', I, 72)

İmam Muhammed'in bu konudaki görüşü oldukça açık ve kesindir. O, müşrik çocuklarının cehennemlik olduğu şeklinde Hz. Peygamber'den nakledilen hadislere hiç değinmemiş, doğrudan konu ile ilgili görüşünü dile getirmiş ve müşriklerin çocuklarının cehennemde olduklarını ifade eden hadisleri kabul etmemiştir. Müşrik çocuklarının cehennemlik olduğunu ifade eden hadislere hiç atıfta bulunmasa bile onun söz konusu hadislerin varlığından haberdar olduğu anlaşılmaktadır. Çünkü kendisine sorulan soru küfür fitratı ile İslam fitratı üzere doğan çocukların hangisinin efdal olduğu şeklindedir. Fakat imam verdiği cevapta çocukların öldükten sonraki durumlarına da temas etmiştir: Bütün çocukların bir olduğunu ve öldüklerinde cennete gideceklerini ifade etmiş ve aksi istikamette bir görüşün, yani müşrik çocuklarını da babaları gibi cehenneme gideceğini söylemenin Allah'ın adaletine uygun olmayacağını dile getirmiştir. Bu konuda varid olan hadisleri esas alan ve onlar etrafında tartışan mezhepler birbirlerinden farklı görüşler ileri sürmüşlerdir. Örneğin, Hariciler müşrik çocuklarının cehennemlik oldukları görüşündedir. Mürciîler ise bu konuda tevakkuf etmişlerdir. Mutezile ise müşrik çocuklarının cennetlik olduğu görüşünü öne sürmüştür. (Malâtî, Tenbih, 33-34)

Benzer şekilde imam Muhammed'e Hz. Peygamber' in ipek elbise giyip onunla namaz kıldığı ile ilgili hadis sorulunca o bu hadisin sahih olmadığını ve $\mathrm{Hz}$. Peygamber'in ipek elbise giydiğini duymadıklarını bilakis ipek elbise ile namaz kılmayı yasakladığını ifade eder. $\mathrm{O}$, bu konuda başka hadisleri dikkate alır ve Hz. Peygamber'in ipek giymeyip onları kadınlara dağıttığını söyler. (Mecmu' II, 623)

\footnotetext{
${ }^{3}$ Müşrik çocuklarının âhiretteki durumları ile ilgili olarak nakledilen hadisleri Hz. Peygamber tarafından stratejik bir yaklaşım ve tedricilik prensibinin uygulanması olarak izah etmeye çalışan bir çalışma için bkz: Arif Aytekin, "isslamda Müşrik Çocukları Meselesi", AÜiFD, (30), Erzurum 2008, 120-138. Biz bu makalede dile getirilen yaklaşıma katılmamaktayız. Çünkü, bize göre bu yaklaşım meseleye çözüm getirmekten öte meseleyi daha karmaşık bir hale getirmektedir. Ayrıca tedricilik prensibinin itikatla, ahiretle ilgili meselelerde söz konusu olamayacağını düşünmekteyiz.
} 
İmam Muhammed'in hadisleri değerlendirmede başka hadisleri esas aldı̆ııı gösteren örneklerden bir diğeri de el öpme konusu ile ilgili hadislerdir. $\mathrm{O}$, el öpme konusunda başka hadisleri değil de Hz. Peygamber'in elinin ve başının öpüldüğüne dair rivayetleri esas alarak bir kişinin kardeşinin elini, başını ve omuzunu öpmesinde bir mahzur olmadığını ifade etmektedir. (Mecmu' I, 83)

İmam Muhammed'e “Yemen'de ve Şam'da bir topluluk çıkacağı ama Medine'nin onlardan daha hayırlı olacağını ifade eden bir hadis sorulur. $O$ da bu şekilde bir hadis nakletmediklerini aksine Haremeyn hadisini naklettiklerini söyler. Bu hadislerin hangi hadisler olduğunu dile getirmez. Ancak, anlaşlan o ki imam Muhammed şehirler hakkında da hadisler uydurulduğunu ima etmekte ve bunlar içinde sahih olanlara işaret etmektedir. (Mecmu' II, 607)

\subsection{Hadis Hz. Peygamber'in Şanına Yakışmayan Bir İçerikte Olmamalı}

$\mathrm{Hz}$. Peygamber, bir peygamber olması hasebiyle bir takım vasıflarla muttasıftır. $\mathrm{O}$, peygamberlik vazifesini en güzel şekilde yerine getirir. Hz. Peygamber'e peygamberlik vazifesini ihlal edici bir takım şeyler isnad etmek doğru değildir. Bu tür isnatlardan $\mathrm{Hz}$. Peygamber' in peygamberlik şanının korunması gerekmektedir. Yine Hz. Peygamber Allah'ın emirlerini yerine getiren, yasakladığı şeylerden kaçınan ve bu hususta çok hassas olan bir şahsiyettir. Hz. Peygamber'in davranışlarında herhangi bir tutarsızı̆̆ın olması mümkün değildir. Dolayısıyla Hz.Peygamber' in söyledikleri ile yaptıkları arasında çelişki arz eden bir takım rivayetleri de ona nispet etmekten kaçınmak gerekmektedir. İmam Muhammed kendisine aktarılan hadisleri bu esaslara dayanarak yorumlamaktadır. Çünkü o, Hz. Peygamber hakkında yalan uydurulduğunun farkındadır. Ayrıca cahil ravilerin rivayetlerinin de bir çok sorun taşıldı̆ııın bilincindedir. Bu nedenle onun bir hadisi değerlendirmede esas aldığı noktalardan birisi de hadiste ifade edilen şeyin $\mathrm{Hz}$.Peygamber'in peygamberlik şanına yakışmayacak bir anlam taşımamasıdır. Bu tür rivayetleri ravisinden ya da geçtiği hadis kitabından dolayı kabul etmek daha başka problemlerin doğmasına neden olmaktadır. İmam Muhammed'in sağlıklı bir peygamber anlayışııın oluşturulmasını sürekli gündemde tuttuğu ve bu hususta taviz vermediği anlaşılmaktadır. Burada onun, $\mathrm{Hz}$. Peygamber' in peygamberlik şanına yakışmayan bir anlam içeren rivayetlere karşı tutumunu gösteren bir örnek üzerinde durulacaktır.

İmam Muhammed'e Hz. Peygamber'in daha önce ezberinde olan ama sonradan unuttuğu ayetlerin olduğunu ifade eden hadis sorulur. Kütüb-i Sitte'de geçen bu hadis Hz. Aişe tarafından rivayet edilmektedir. Bir gece Hz. Peygamber mescitte bir adamın okuduğu Kur'an'ı işitir ve şöyle der: Allah ona merhamet etsin! Unuttuğum falan surenin şu şu âyetlerini bana hatıllattı" (Buhari, "Fedail" 26;) İmam Muhammed bu hadisin sahih olmadığııı dile getirir. Çünkü Allah'ın Kitab'ından herhangi bir şey unutulup gitmez, yok olmaz. Ayrıca $\mathrm{Hz}$. Peygamber Kur'an'ı bilen ve onu hifzedendir. (Mecmu' II, 615) Görüldüğü gibi imam Muhammed Hz. Peygamber'in peygamberlik şanı ile uyuşmayan bir rivayeti asla ona isnad etmemektedir. Çünkü, Kur'an âyetlerini tebliğ etmekle görevlendirilen bir peygamberin kendisine indirilen âyetleri unutması onun peygamberlik şanını zedeler ve ona olan güveni sarsar. 
Kadir DEMIRCi

\subsection{Hadis Dinin Bir Esasına Aykırı Olmamalı}

İmam Muhammed hadisleri yorumlarken dikkate aldığı kriterlerden biri de dinin temel esaslarıdır. Şayet bir hadis dinin temel bir esasına aykırıık taşıyorsa o, bu hadisi kabul etmez. Çünkü daha önce ifade edildiği üzere imam hadisler konusunda bir bakış açısına sahiptir ve bu bakış açısını dikkate alarak hadislere yaklaşmaktadır. Bu bakış açısında Hz. Peygamber hakkında çokça hadis uydurulduğu gerçeği yer almaktadır. Bu nedenle imam Muhammed din hususunda sağlam bilgileri esas almakta, raviler aracılığı ile nakledilen hadisler yoluyla gelen bilgiler ile dinin sağlam bilgileri çeliştiğinde söz konusu hadisleri çok rahatlıkla terk edebilmektedir. İmam Muhammed bu tür hadislerin hangi hadis kaynaklarında yer aldığı, hangi raviler tarafından rivayet edildiği üzerinde hiç durmaz. Ya da başka alimlerin o hadis ile ilgili neler söylediklerine iltifat etmez. Kesin, doğru bilgileri esas alarak hadis rivayetini dinin esasları çerçevesinde değerlendirerek bir yoruma ulaşır.

İmam Muhammed'in bu yaklaşımına göre bir kurala, esasa aykırı olan hadis sahih değildir. Örneğin, ona, kabirler arasında ayakkabısı ile gezen birini gören Hz. Peygamber'in bunu yasakladığı hadisi sorulur. O, bu hadisin sahih olmadığını ifade eder. Çünkü kabirler arasında ayakkabı ile gezmekte bir beis yoktur. Çirkin olan kabirleri çiğnemektir. (Mecmu' I, 124) Görüldüğü gibi imam burada yasağı gerekli kılacak bir şeyi bulmaya çalışır. Ancak hadiste böyle bir şey yoktur. Bu aynı zamanda aklî bir değerlendirmedir. Onun bu yaklaşımından şu da anlaşılıyor ki hadisler doğru bir şekilde nakledilmemiştir. Belki de kabirlerin çiğnenmemesi konusunda bir uyarı $\mathrm{Hz}$. Peygamber tarafından yapılmış olabilir. Nitekim o, bu ihtimali gündeme getirmekte ve hadisin böyle bir anlam taşıyabileceğini söylemektedir.

İmam Muhammed namazda konuşulmaması gerektiği kanaatindedir. Ona göre namazda Kur'an tilavetinin dışında bir şey okunmaz. Bu onun kabul ettiği namazla ilgili temel bir esastır. O, bu esasa aykırı olan rivayetleri çok sert bir şekilde reddeder ve onları fasid, batıl, muhal olmakla niteler. Çünkü ona göre Rasulullah ne farz namazlarda ne de nafile namazlarda dünya kelamı söylememiştir. (Mecmu' II, 605)

Kişi cennete ameli ile girer bu Kur'anî bir hakikattir. Bu esasa aykırı olan hadis sahih değildir. Hiç kimse ameli ile cennete giremez hadisi bu lafızla sahih değildir. (Mecmu' II, 616)

İmam Muhammed'in bakış açısına göre fayda vermeyen rivayetler terk edilmelidir. Nitekim o, “İsrailoğulları olmasaydı et bozulmazdı” (Buhari, Enbiya, 27, 3218; Müslim, Rada', 19, 2673) hadisini bilmediklerini bu hadisin ashab-ı hadisin tuhaf rivayetlerinden ve ziyadelerinden olduğunu ifade eder ve devamında şu yorumu yapar. İnsana fayda vermeyen hadislerle meşgul olunmamalıdır. Bir asla dayanmayan hadislere iltifat edilmemelidir. İnsanlar Allah'ın Kitabı'na ve Peygamber'in sünnetine yönlendirilmelidir. Çünkü, bu ikisinde kalbin şifası, sadrın cilası bulunmaktadır. Hadiste tam olarak ifade edilmese de etin bozulmasının İsrailoğullarıyla ilişkilendirilmesi onların etleri uzun zaman saklamaları ve ihtiyaç sahiplerine dağıtmamalarından dolayıdır. İmam Muhammed'e göre ise etin saklanması kötü bir şey değildir. Etin bir kaç gün saklanması caizdir. (Mecmu' II, 617) 
İmam Muhammed'e "Sizden biri gece uyuduğunda şeytan ensesine üç düğüm atar. Her düğümde uzun uzun uyu der. Kişi uyanıp Allah’ı zikrettiğinde bir düğüm çözülür. Eğer abdest alırsa bir düğüm daha çözülür. Şayet namaz kılarsa bir düğüm daha çözülür ve canlı, neşeli dinç bir şekilde sabahlar. Eğer gece uyanmadan uyumaya devam ederse kötü bir halde, tembel bir şekilde sabaha çıkar." (Buhari, Teheccüd, 12, 1091; Müslim, 28, 1295) hadisinin anlamı sorulur. İmam Muhammed, bu hadisin ashab-ı hadisin rivayet ettiği hadislerden ve onların bidatlerinden olduğunu söyler. Ona göre bu hadis sahih değildir. (Mecmu' II, 619)

İmam Muhammed'e “Allah'ın hicabı nurdur. Eğer hicabını açmış olsa yüzünün aydınlığı gözünün gördügü her şeyi yakar, yok ederdi" hadisi sorulmuştur. Bu hadisin bu kısmı Müslim'in iman bölümünde bab başlığında yer almaktadır. Babın altında zikredilen hadis ise şu şekildedir: $\mathrm{Hz}$. Peygamber ashabı ile bulunduğu bir sırada ayağa kalkar ve şu beş cümleyi söyler: Allah uyumaz ve ona uyumak yakışmaz. O mizanı indirir ve kaldırır. Gündüzün amelinden önce gecenin ameli ona arz olur. Gecenin amelinden önce de gündüzün ameli ona arz edilir. Onun hicabı nurdur. Şayet o hicabını açmış olsa yüzünün ışı̆ı, gözünün ihata ettiği her yer yanardı." (Müslim, İman, 78, 179) İmam Muhammed bu hadisin batıl olduğunu ifade eder. Ona göre bu hadis Müşebbihe'nin ve mülhidlerin dile getirdiği rivayetlerdendir. Allah bu gibi sıfatlardan münezzeh ve yücedir. Çünkü o şöyle buyurmuştur: "Onun eşi ve benzeri yoktur. O her şeyi işiten ve görendir" (Şura, 42:11) Başka bir âyette de şöyle buyrulmuştur. "Gözler onu göremez. O gözleri ihata eder. O, çok latif ve her şeyden haberdardır”. (En'âm, 6:103 Mecmu' II, 621)

İmam Muhammed'e göre bir rivayet bir fayda içermeli ya da bir fesadı önlemelidir. Aynı şekilde fesada, zarara yanlışa sebebiyet vermemelidir. Çünkü ona göre böyle olan hadis imam Muhammed'e göre sahih değildir. Bunun örneği ister farz namazda ister nafile namazda olsun kişinin uzun uzun kıraatte bulunmasıdır. İmam Muhammed, farz namazda bu şekilde uzun kıraatte bulunmayı doğru bulmaz. Bunun zararına işaret eder. Farz namazdaki uzun kıraat arkada namaz kılan cemaat için bir fesada dönüşür. $O$, farz namazı münferit olarak kılan kişinin de namazında uzun kıraatte bulunmasını doğru bulmaz. Bu da kişiye bıkkınlık verebilir. Namazda en doğru olan kısa sureler okumaktır. Fatihadan sonra üç ayet okumak yeterlidir. Hz. Peygamber'in farz namazlarda uzun surelerden okuduğuna dair haberler bize ulaşmamıştır. Ancak kişi nafile namazında uzun sure okursa bunda bir mahzur yoktur. (Mecmu' I, 81)

Namazda Kur'an ayetleri ve mütevatir hadislerle gelen dualar dışında dua etmek caiz değildir. İmam Muhammed bu tür duaları namazda konuşma olarak değerlendirmektedir. Ona göre ister rükûda ister secdede bu tür dua etmek caiz değildir. (Mecmu' I, 137)

\subsection{Yorumda Peygamberî Muradın Gözetilmesi}

İmam Muhammed'in hadis yorumunu ortaya koyan örneklerden biri de onun bazı hadislerde yer alan ifadeleri zâhirî lafızlarının intiva ettiği anlamlara hamletmeyip, aksine lafızlarla kastedilen manaya hamletmesidir. Bunun örneklerinden biri $\mathrm{Hz}$. Peygamber'in evim ile minberim arası cennet bahçelerinden bir bahçedir diye bilinen meşhur hadis hakkında yaptığı yorumdur. Ebu Hureyre'den rivayet edildiğine göre Hz. Peygamber şöyle buyurmuştur: “Evimle minberim arasın- 
Kadir DEMiRCi

daki alan cennet bahçelerinden bir bahçedir. Minberim de havzım üzerindedir." (Buhari, Fedâilu'lMedine, 13, 1789; Müslim, Hac, 92, 2465) hadisinin yorumu sorulduğunda, o, bu hadisi tevil eder ve hadiste geçen 'cennet bahçesi' ifadesinin bir Arap deyimi olduğunu belirtir. Bir yer temiz, pak olduğunda Araplar o yer için 'cennet bahçesi' tabirini kullanır. Hz. Peygamber'in de minberi ile evi, yani kabrinin bulunduğu alan da pak, temiz bir alandır. Orada zulüm, ihanet gibi şeyler olmamıştır. Aksine orada, minberinden insanlar hidayete, dine, kurtuluşa çağrılmıştır. Onun çağrısına kulak verenler, davetine uyanlar kurtuluşa ererler ve sonunda cennete vasıl olurlar ki hadiste kastedilen mana da budur. (Mecmu' II, 625)

İmam Muhammed'in yaptığı bu yorum, herkes için istifade edilecek bir mesaj içermektedir. $\mathrm{Hz}$. Peygamber'in minberinden insanlar cennete davet edilmiş, insanı cennete götürecek amellerin müjdesi verilmiştir. Orası hakkın, hakikatin, iyinin, güzelin ifade edildiği temiz ve mübarek bir mekandır. Hadisin bu şekilde anlaşılması herkes için bir mesaj içerecektir. Ancak özellikle geniş kitleler bu tür hadisleri genellikle zâhirî anlamları ile anlama eğilimi içerisindedirler. Bundan dolayı kitleler hadiste ifade edilen minber ile kabir arasındaki mekanı cennet bahçesi olarak değerlendirmekte ve orada namaz kılmak için büyük bir izdiham ve hatta birbirlerini rahatsız edecek boyutta davranışlar sergileyebilmektedirler. İnsanlar mekanı kutsamakta ve orada iki rekat namaz kılmayı bir kurtuluş olarak görmektedirler. Halbuki gerçek kurtuluş o mekanda $\mathrm{Hz}$. Peygamber'in dile getirdiği hakikatlere, öğütlere uygun bir hayat yaşamaktadır. Gerçek kurtuluş Hz. Peygamber'in o mekanda dile getirdiği uyarılarından ders alıp günahtan, çirkin ve yanlış işlerden uzak kalmaktadır.

İmam Muhammed'in hadislerde dile getirilen ifadelerin lafızlarına takılı kalmadığı onları başta Arap dili olmak üzere dinin diğer ilke ve esaslarını da dikkate alarak yorumlama cihetine gittiği görülmektedir. O, bu tavrını Kur'an âyetlerinin anlaşılmasında da göstermektedir. Örneğin, "Sizden cehenneme uğramayacak kimse yoktur. Bu Rabbinin kesinleşmiş bir hükmüdür" (Meryem, 19: 71) ayetinin anlamı hakkında şu yorumu yapmaktadır. Bu ayet genel olarak Müslümanların (el-âmme) anladıkları gibi herkesin cehenneme gireceği anlamında değildir. Zira böyle olsaydı o takdirde şu âyetlere aykırı bir durum ortaya çıkardı. Allah Teala şöyle buyurmuştur: "En büyük dehşet de onları kaygılandırmaz. Melekler onları, 'İşte bu size vaad edilmiş olan mutlu gününüzdür' diyerek karşılar" (Enbiya, 21: 103) Yine Allah Teala başka bir âyetinde "O gün onlara korku da yoktur onlar mahzun da olmayacaklardır” (Yunus: 62) buyurmuştur. İmam Muhammed’e göre Kur'an Arap lisanında indirilmiş bir kitaptır. O nedenle Arap dilinin inceliklerini dikkate almak gerekmektedir. Arap dilinde 'vurûd' kelimesi bir yere girmek, dahil olmak anlamına değil oraya varmak, oradan geçmek, onu görmek anlamına gelir. Örneğin, Arap dilinde şöyle denir: "veredna'l-bi're" Arap bu ifade ile kişinin kuyunun içine girmesini murat etmez. Oraya kuyunun yanına yaklaştığını, onu gördüğünü ifade eder. Eğer âyeti genel olarak insanların anladığı gibi herkesin cehenneme gireceği şeklinde anlayacak olsak bu durumda başka ayetlere muhalif bir durum ortaya çıkar. Nitekim Allah Teala müminler hakkında "Onun uğultusunu işitmezler" (Enbiya: 102) buyurmuştur. Eğer cehenneme girecek olsalardı onun uğultusunu işitirlerdi. Dolayısıyla âyetin anlamı genel olarak halkın anladığı gibi de- 
ğildir. Herkes cehennemi görecek, müşahede edecek ona yaklaşacak demektir, içine girecek demek değildir. (Mecmû', II, 594)

İmam Muhammed'in hadis metinlerinde dile getirilen ifadelerde gayeyi esas aldığını gösteren örneklerden biri de şiir ile ilgili hadistir. Buhârî́nin de rivayet ettiğine göre Hz. Peygamber şöyle buyurmuştur: "Bir kimsenin içinin irinle dolması şiirle dolmasından daha hayırlıdır" (Müslim, Şiir, 1, 4193) Imam Muhammed bu hadisten hareketle mutlak manada şiiri kötü bir şey olarak algılamaz. $\mathrm{O}$, ilim ehlinin hadiste ifade edileni her şiir için doğru bulmadığını dile getirmiştir. $\mathrm{O}$ şiiri iki kısma ayırır. Biri caiz diğeri de haram olan şiirdir. Caiz olan içinde öğüt, hikmet, ilim, irfan, edeb, ahlak bulunan şiirdir. Haram olan ise fitne, fesad, içerendir. (Mecmu' II, 629) İmam Muhammed'in bu yaklaşımı da oldukça dikkat çekicidir. Tarihimizde yer alan geçmiş alimlerimizden bu tür yaklaşımlar görmemiz hadislere karşı nasıl bir tasavvur içinde olmamız gerektiği açısından önem arz etmektedir. Çünkü günümüzün en önemli sorunlarının başında hadislerin anlaşılıp yorumlanması meselesi gelmektedir. Genellikle hadisler Hz. Peygamber'in muradı dikkate alınmadan ve en önemlisi başka hadisler ve ayetler hesaba katılmadan tek tek parçacı bir şekilde yaklaşılarak ele alınmakta ve değerlendirilmektedir. Hadisler üzerinde bu tür parçacı bir okuma onların yanlış anlaşılmasına ve netice olarak yanlış bir din tasavvuruna sebebiyet vermektedir. O nedenle geçmiş alimlerimizden hadislerin anlaşıması ile ilgili bu tür örnekler, hadis anlayışımızı güçlendirecek ve bize bir hadis bilinci kazandıracak mahiyette örneklerdir.

İmam Muhammed'in hadis yorumunda tutumunu gösteren örneklerden biri de bir başkasının evinin içine izinsiz bakan ve bu esnada gözünü sakınmayan kişi hakkındadır. İmam bunun doğru bir davranış olmadığını söyler. Ona göre kasıtlı olarak mümin kardeşinin mahremini ihlal eden kişinin tevbe ve istiğfarda bulunması gerekir. Onun verdiği cevapta ve bu yaklaşımında dikkat çeken husus bir başkasının evine izinsiz nazar edenin ve gözünü sakınmadan bakanın gözünün çıkarılması gerektiğini ifade eden hadisi dikkate almamasıdır. Bu durumda o, ya bu hadisten haberdar değildir ya hadisi sahih kabul etmemektedir ya da hadisi zâhirî anlamı ile anlamamaktadır. Son tahlilde o, hadisi bir kişinin kardeşinin mahrem haline saygısızlığın büyük bir günah olacağı şeklinde değerlendirmektedir. (Mecmu' I, 73)

İmam Muhammed anlamı tuhaf olan, ne demek istediği tam anlaşılmayan hadisleri de makul bir anlama tevil eder. İmam Muhammed'e göre bu hadis tuhaf mana içermektedir. $\mathrm{O}$, bu hadis hakkında "Allah'ın adının dışında kesilen hayvanın etini yemeyin şeklinde tevil edilir" demektedir. (Mecmu'l, 144)

\section{Sonuç}

Zeydiyye, Emevî saltanatına karşı görüş ve eleştirilerini dile getiren ve bu uğurda hayatını ortaya koyan Zeyd b. Ali'nin yolunu takip edenleri ifade eden itikadi ve fikhi bir mezheptir. Zeyd b. Ali'nin fikri ve siyasi duruşu, onu takip eden Zeydîler üzerinde büyük tesir uyandırmış ve mezhep mensupları her türlü zorluklara, baskı ve engellemelere rağmen ilmî ve siyâsî mücadeleyi sürdürme azim ve gayretiyle İmam Zeyd'in yolundan gitmeye gayret etmişlerdir. Siyâsette muhalif, ilimde eleştirel olan bu duruş, Zeydî literatüründe de temsil edilmiştir. Kâsım er-Ressî (ö.246/860) ve to- 
Kadir DEMIRCi

runu Hâdî ile'l-Hak Yahya b. Hüseyin (ö.298/901) onun en önemli temsilcileri arasında yer alır. Çalışmamıza konu edindiğimiz, Hadi ile'l-Hak'ın oğlu Muhammed de, bu duruşu devam ettirmiştir. Biz onun söz konusu eleştirel yaklaşımını hadis yorumu bağlamında ele aldık.

Zeydi geleneğinden eleştirel anlayışı devralan İmam Muhammed b. Yahya, hadis ilminde bir mukallit değil, aksine özgün ilmi şahsiyeti olan bir alim olmuştur. İmam Muhammed'in bir mukallit olmamasının en somut göstergelerinden biri hadis tespit ve yorumunda hadis imamlarına ve onların kaynaklarına atıf yapmamasıdır. Bu durum onun hadis kaynaklarına ve oradaki rivayetlere muttali olmadığı şeklinde anlaşılmamalıdır. Aksine o mahfûzâtında çok sayıda sahih hadise sahip olduğu gibi muhalifleri tarafından rivayet edilen hadislere de vakıf bir muhaddistir. Bu hadisleri rivayet eden ravilere ve muhaddislere, hatta eser sahiplerine kitabında atıf yapmaması onun nakilci ve mukallit bir âlim değil özgün bir âlim olduğunun en açık göstergesidir. En önemlisi ise onun bu hadisleri değerlendirmeye tabi tutacak ilmî bir dirâyete sahip olmasıdır. $O$, çok açık yüreklilikle hadisin hangi kaynakta ve hangi muhaddis tarafından nakledildiğine bakmaksızın hadisin muhtevası hakkında cesurca değerlendirmeler yapabilmektedir.

İmam Muhammed'in ifadelerinden anlaşıldı̆̆ına göre o sünnet ile hadisi birbirinden ayırmaktadır. Onun nazarında sünnet Müslüman için örnek alınacak bir asıldır. Müslüman Hz. Peygamber'in Sünnetine yönelmeli, faydalı, güzel şeyleri almalıdır. Sünnet diye onun tabiriyle insanı derin deryalara sokacak mahiyette olan acayip, tuhaf, faydasız şeylere iltifat etmemelidir. İmam Muhammed'e göre hadisler bir takım problemleri taşıması sebebiyle mutlaka tenkit edilmelidir. $\mathrm{O}$, raviler tarafından nakledilen hadis gerçeğinin son derece farkındadır. Nitekim onun bu farkındalığını gösteren ifadelere eserlerinde sık sık rastlamak mümkündür. En başta Kur’an’a aykırı mahiyette pek çok hadis bulunmaktadır. Ayrıca birtakım çevreler tarafından uydurulmuş hadisler söz konusudur. O, bazen bu çevreleri Ashab-ı Hadis, bazen Haşviyye, bazen Müşebbihe, bazen mülhidler olarak adlandırmaktadır. Yine cahil kişiler tarafın rivayet edilmiş hadisler bulunmaktadır. Bunlar içeriği Kur'an ve Sünnet ile çoğu zaman örtüşmeyen rivayetlerdir. Bu gibi rivayetler için Allah'ın Kitabı'nın şahitliğine müracaat edilmeli, o tasdik edici bir merci olarak kullanılmalıdır.

İmam Muhammed'in sahih hükmünü verip kabul ettiği hadisler içerisinde Buhari ve Müslim'de yer alan hadisler de bulunmaktadır. Aynı şekilde batıl, fasid, sahih değildir diye hüküm verip reddettiği hadisler içinde Buhari ve Müslim hadisleri de yer almaktadır. Anlaşılan o ki onun yaşadığı dönemde bugün için temel hadis kaynakları olarak bilinen Muvatta, Musannef, Müsned, Kütüb-i Sitte, gibi hadis kaynakları meşhur ve mütedavil değildir. Bu durum, İmam Muhammed'in nakledilen rivayetlerden habersiz olduğu anlamına da gelmemektedir. Ama şu açıktır ki onun üzerinde, kendi mezhep mensuplarına ait olduğu ileri sürülen hadis kaynaklarının da bir baskısı ve ağırlığı gözükmemektedir. Zira o, eserlerinde kendi mezhep imamı Ahmed b. İsa'nın (ö.246/860) Emâlî adlı eserine de atıf yapmamakta, tamamen kendi ilmî hürriyeti ile hadislere yaklaşmakta Kur'an ve Sünnet bilgisi çerçevesinde onları çok rahatlıkla değerlendirebilmektedir. Açık bir şekilde hadisleri nakleden ravilerin sika olması gerektiğinden söz etmekle birlikte bu bağlamda onun temel olarak ilgilendiği, hadisin kim tarafından rivayet edildiği veya hangi hadis kaynağında yer aldığı değil, daha 
ziyade hadisin içeriğidir. Dolayısıyla ravinin sika olması da onun nazarında tek ve nihai kriter değildir.

İmam Muhammed hadisin tespitinde olduğu gibi hadislerin yorumlanmasında da Kur'an'ı baş ucu kitabı olarak kullanır. Kur'an'ın içeriği istikametinde hadisleri anlamaya ve yorumlamaya çalışır. Öncelikle hadisin muhtevası Kur'an'ın muhtevası ile çelişki arz ediyorsa, o hadisin Hz. Peygamber'e aidiyetini benimsemez. Bu konuda onun tavrı çok net ve kesindir. Ayrıca imam Muhammed hadislerin yorumlanmasında üzerinde icma edilmiş sahih sünneti, ya da çok bilinen maruf sünneti bir kriter olarak kullanır. Sahih ve maruf sünnete muhalif anlam içeren hadisleri, ya reddeder ya da tevil etmek suretiyle değerlendirir. İmam Muhammed hadisleri yorumlamada aklı da dikkate alır. $\mathrm{Hz}$. Peygamber'in akla aykıı tuhaf şeyler söylemesini kendisinin peygamberlik şanına yakışmayan bir husus olarak kabul eder. Hadisleri, dinin temel esasları çerçevesinde yorumlar. Çünkü Hz. Peygamber hikmet sahibi bir peygamberdir. Onun söyledikleri bir fayda ve gaye taşımaktadır. $\mathrm{Hz}$. Peygamber'in dinin temel esasları ile örtüşmeyen şeyler söylemesi düşünülemez. Görüldüğü gibi imam Muhammed, hadisleri yorumlamada çok hassas hareket ederek birden fazla kriter kullanır. Onun hadisler konusunda bu denli hassas ve dikkatli olmasının ardında $\mathrm{Hz}$. Peygamber hakkında hadis uydurma gerçeği yatmaktadır. İmam Hz. Peygamber hakkında yalan söylendiğinin son derece farkındadır, bu yalanların sadece din düşmanları (mülhidler) tarafından değil aynı zamanda mezhep taassubuyla da üretildiğinin bilincindedir. Ona göre belli bir mezhebe bağlı olanlar kendi mezhebi anlayışları doğrultusunda hadis uydurabilmişlerdir. Bütün bunlardan hareketle o hadislerin sadece güvenilir raviler tarafından nakledilmesini yeterli görmez. Hadisleri daha farklı kriterlerle ve daha geniş bir çerçeveden değerlendirmeyi arzu eder. Ancak bu şekilde sağlam ve sahih bir din anlayışına sahip olmak mümkün olabilir. Aksi halde bidatlerin hakim olduğu bir din anlayışı ortaya çıkar.

İmam Muhammed'in hadisleri yorumlamada dikkat çeken yönlerinden biri de lafızcı bir tavır takınmayıp Hz. Peygamber'in muradını keşfetmeyi hedeflemesidir. Hiç şüphesiz Hz. Peygamber Arap dilinin özellikleri ile konuşmuştur. O bu gerçeğin farkında olarak hadislere yaklaşır. Dolayısıyla hadisleri yorumlamada kelimelerin zahirî anlamlarına takılıp kalmaz. Onlarla neyin kastedildiği üzerinde durur ve $\mathrm{Hz}$. Peygamber'in muradının ne olduğunu bulmaya çalışır. Onun için önemli olan $\mathrm{Hz}$. Peygamber'in vermek istediği mesajdır ve hadisten bir fayda temin etmektir. Aynı şekilde hadis rivayetinde bir takım hataların, yanlışlıkların yapıldığını da bilmekte ve bütün bu problemler çerçevesinde hadise yaklaşmaktadır. Onun hadis gerçeği ile ilgili farkındalıkları, bugün bizim için de önemli olan hususlardır.

İmam Muhammed'in hadisleri yorumlamada Kur'an'ı öne çıkarması, bugün için bizim de dikkate almamız gereken bir tavırdır. Ancak bunu yaparken dikkatli olunması gerekir. Çünkü hadislerin yorumlanmasında Kur'an'ın kullanılması da sübjektif bir karakter taşıyabilmektedir. Şu var ki hadis yorumlarında Kur'an'ın inmal edildiği, şahıs ve eser karizmalarının öne çıkartılarak rivayetlere yaklaşılmasının revaçta olduğu bir dönemde imam Muhammed'in Kur'an merkezli yorumu bizim için örnek teşkil etmektedir. Onun dikkat çektiği yönlerden biri de, Kur'an -Sünnet bütünlüğünü gö- 
Kadir DEMIRCi

zetme konusundaki hassasiyetidir. $\mathrm{O}$, hem hadislerin sıhhatinin tespit edilmesinde hem de muhtevalarının anlaşılıp yorumlanmasında Kur’an sünnet bütünlüğünü son derece önemsemektedir.

\section{Kaynaklar}

Aytekin, Arif, (2009). “İslam'da Müşrik Çocukları Meselesi”, Atatürk Üniversitesi İlahiyat Fakültesi Dergisi, 120-138.

Buhârî, Muhammed, (2002). Sahihu'I-Buhârî, Dâru ibn-i Kesîr, Beyrut.

Demirci, Kadir, (2018). "Zeydî Hadis Yorumu: İmam el-Mütevekkil Ale'llah Ahmed b. Süleyman (ö.566/1176) Örneği”, e-Şarkiyat Illmi Araştırma Dergisi.

İbn-i Hanbel, A. (2001). el-Müsned, nşr: Şuayb el-Arnâût.

Malâtî, Ebu'l-Hüseyn, (1968 ). et-Tenbih ve 'r-Red alâ ehli'l-ehvâi ve'I-bidei', thk: Muhammed Zâhid el-Kevserî, II. bsk. Beyrut.

Muhallâ, Hamid, A. (2002). El-Hadâiku'I-Verdiyye fî Menâkıbi Eimmeti'z-Zeydiyye, thk: Murtaza Mahatvarî, Mektebetu Merkez-i Bedr, San'a.

Murtaza Lidinillah, Muhammed b. Yahya b. el-Hüseyin, (2002). Mecmû'u Kütübi ve Resâil-i imam Murtaza Muhammed b. Yahya, Abdülkerim Ahmed Cedban, Mektebetü't-turâsi'l-islâmî, Sa'de.

Müslim, Haccâc, (2006). Sahîh-u Müslim, thk: Nazar b. Muhammed, Dâru Tayyibe.

Ümit, Mehmet, (2018). “Zeydiyye Ekolü’nün Erken Dönem Temel Kaynakları”, Halil ibrahim Bulut (edit.), Mezheplere Göre Klasik Kaynaklar ve Özellikleri, Ensar yayınları, İstanbul, 91-162.

Ümit, Mehmet, (2010). Zeydiyye-Mu'tezile Etkileşimi Zeyd b. Ali'den Kasım er-Ressi'nin Ölümüne Kadar, İstanbul.

Üzüm, ilyas, (2013). "Zeydîler" Diyanet İslam Ansiklopedisi, İstanbul.

Vecih, Abdüsselam, (1999). A'lâmü'l-müellifîne'z-zeydiyye, Müessesetü Zeyd b. Ali es-Sekâfiyye, San'a. 